\title{
Forecasting GDP based on the assessment of cyberspace development
}

\author{
Malika Davliatova ${ }^{1, *}$, Yuriy Starodubtsev ${ }^{1}$, Olga Voronova $^{1}$, and Gennady Starodubtsev ${ }^{1}$ \\ ${ }^{1}$ Peter the Great St. Petersburg Polytechnic University, 195251, Polytechnicheskaya 29, Russia
}

\begin{abstract}
The relevance of the topic is due to the fact that an operational assessment of the dynamics of the main macroeconomic variables, including GDP, is a prerequisite for an effective economic policy. This work substantiates the consideration of the technological level of development of cyberspace as a predictor of the current dynamics of GDP along with data from official statistics. The scientific significance of the study: the relationship between the dynamics of the development of cyberspace and the dynamics of changes in the volume of GDP is revealed, which allows us to predict changes in the volumes of GDP, as well as the dynamics of changes in world capital, taking into account the various stages of development of national economies; statistical relationship between the influx of investment in fixed assets and the growth rate of GDP is identified.
\end{abstract}

\section{Introduction}

To provide an opportunity to assess the current situation regarding economic growth, it is important to develop tools for assessing and short-term forecasting the dynamics of changes in GDP. GDP is a macroeconomic indicator showing the total market value of all final products and services intended both for domestic consumption and for exports produced within one year in the country in all sectors of the economy.

The relevance of the research is due to the fact that an operational assessment of the dynamics of the main macroeconomic variables, including GDP, is a prerequisite for an effective economic policy [1-4].

Cyberspace is a system-forming element of the modern economy that ensures the functioning of all sectors of the economy [5].

The IT services market is transnational, so quantifying it nationwide is a rather complicated task. But existing researches show that this segment is growing in volume much faster than the Russian economy as a whole [6-10].

The total economy of the Internet industry in Russia, including the mobile sector, reached 5 trillion rubles in 2019. When assessing the country's GDP of 100 trillion rubles, the share of the economy of the Internet industry is $5 \%$ [11].

\footnotetext{
* Corresponding author: malika.davliatova@gmail.com
} 
According to estimates by the Russian Association of Electronic Communications (RAEC), in 2018 the contribution of the Internet industry economy to the country's economy amounted to 3.9 trillion rubles, which is $11 \%$ more than in 2017 .

The contribution of the mobile economy to Russia's GDP last year at RAEC was estimated at 1.6 billion rubles (an increase of 17\%). So, in 2018, the volume of the ecommerce market amounted to 2 trillion rubles (plus 13\% per year), the marketing and advertising market - 262 billion rubles (plus 17\%), the infrastructure and communications market - 106 billion rubles (plus 17\%), the market digital content - 75 billion rubles (plus $7 \%)$.

The largest influx of investment falls on industrialized countries, which have the most technologically advanced information and telecommunications platform [12-14].

The scientific significance of the research is to identify the relationship between the dynamics of the development of cyberspace and the dynamics of changes in GDP, which allows us to predict changes in GDP, as well as the dynamics of changes in world capital, taking into account the various stages of development of national economies.

World capital is always concentrated in various geographical areas of the world economy [15]. Moreover, the "centers of condensation" of capital over time change their place on the world map. In the framework of the research, the choice of an indicator of the technological level of development of cyberspace as an indicator of the dynamics of changes in GDP, as well as changes in the geographical location of world centers of capital accumulation, is justified.

\subsection{The objective}

The objective of the research is to predict the dynamics of changes in GDP based on an assessment of the technological level of development of cyberspace.

Research tasks are as follows:

1) to analyze and characterize the theory of systemic cycles of capital accumulation;

2) to analyze the dynamics of changes in GDP;

3) describe the process of cyberspace development.

\subsection{Methods}

The research is based on such methods as:

- methods of socio-economic forecasting,

- cluster analysis,

- methods of economic theory

\section{Theoretical framework}

The theoretical framework of the research - the researches of G. Arrighi [16], N.D. Kondratyev [17], F. Braudel [18], T. Picketti [19], E.V. Balatsky [20].

At the turn of the XX-XXI centuries. G. Arrighi, based on the studies of the French historian F. Braudel and the principles of world-system analysis, developed the theory of Systemic Cycle Of Accumulation Of Capital (SCA). F. Braudel drew attention to the fact that the centers of capital accumulation are characterized by a constant change in their geographical location [18]. In the Middle Ages, they were in the north of Italy, in the 17th century they moved to Holland, with the beginning of the 19th century - to Britain, and in the 20th century to the USA. These studies by F. Braudel served as the impetus for the development of G. Arrighi theory of SCA. 
In accordance with the theory of G. Arrighi, in addition to the Kondratieff cycles lasting 40-50 years, there are also secular cycles lasting about 100 years. Each of these cycles forms a new economic leader in the new territory and begins with "material expansion", when investments are mainly directed to the sphere of material production. But a powerful influx of investments in material production, having reached its peak of development, leads to a crisis of overaccumulation of productive capital, profits drop to almost zero, and investments are redirected to the financial sector [20].

The essence of the SCA theory is that each approximately century-old historical period forms its own capital accumulation system, the center or leader of which is the most technologically developed country. Around the leader, a certain core is formed from other developed countries, and the rest of the countries form the periphery of this accumulation cycle.

According to the concept of G. Arrighi [16], the signal crisis of the American cycle of accumulation began in the 1970 s. and continues to this day.

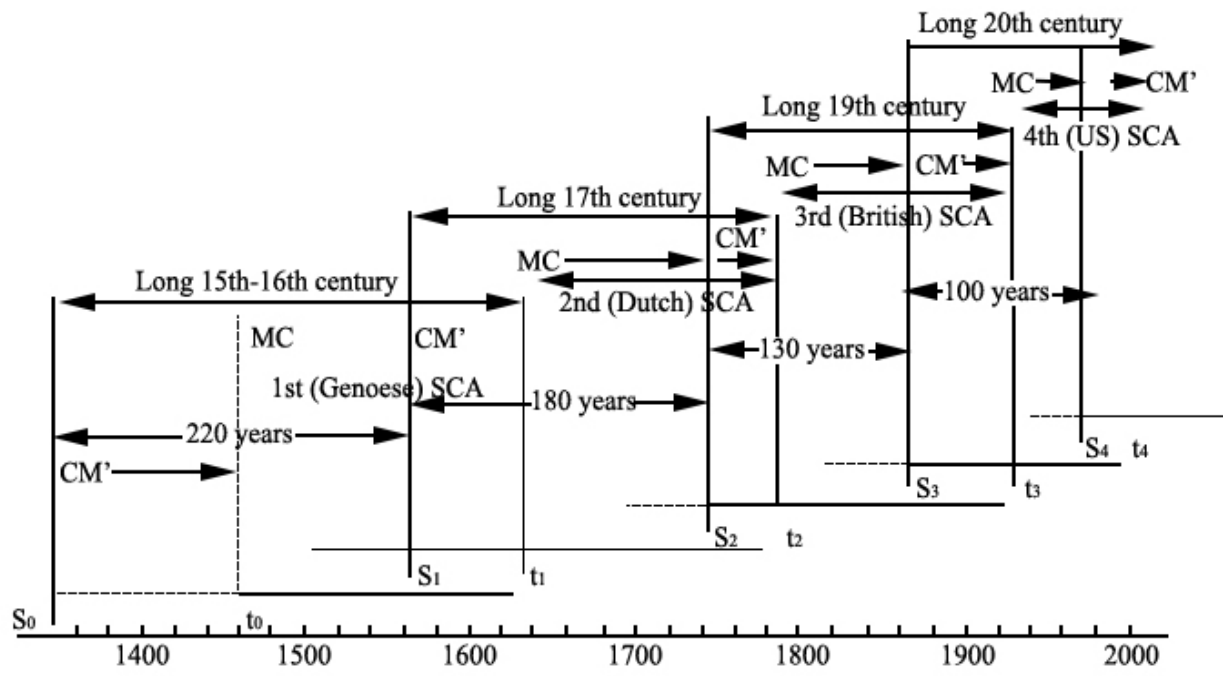

Fig. 1. Scheme of systemic cycles of accumulation of G. Arrighi [1].

World capitals have not yet determined a new world center of capital accumulation, in connection with which there are many formally chaotic actions to identify it [17].

In the framework of the research, the choice of an indicator of the technological level of development of cyberspace as an indicator of the dynamics of changes in GDP, as well as changes in the geographical location of world centers of capital accumulation, is justified.

\section{Dynamics of GDP change}

Gross domestic product (GDP) is a measure of the economic activity, defined as the value of all goods and services produced less the value of any goods or services used in their creation.

The calculation of the annual growth rate of GDP volume is intended to allow comparisons of the dynamics of economic development both over time and between economies of different sizes. 
Table 1. GDP (Nominal) and Foreign Direct Investment Ranking 2019 (Top 12).

\begin{tabular}{|c|c|c|c|c|c|}
\hline Rank & Country & $\begin{array}{c}2019 \\
\text { (billions of \$) }\end{array}$ & Share, \% & $\begin{array}{l}\text { Foreign Direct } \\
\text { Investment } 2019 \\
\text { (billions of \$) }\end{array}$ & $\begin{array}{l}\text { International } \\
\text { Telecommunicati } \\
\text { on Union: The } \\
\text { ICT Development } \\
\text { Index } 2017 \\
\end{array}$ \\
\hline 1 & $\begin{array}{l}\text { United } \\
\text { States }\end{array}$ & 21439.45 & 24.8 & 258.39 & 8.18 \\
\hline 2 & China & 14140.16 & 16.3 & 203.5 & 5.6 \\
\hline 3 & Japan & 5154.48 & 5.95 & 25.88 & 8.43 \\
\hline 4 & Germany & 3863.34 & 4.46 & 105.28 & 8.39 \\
\hline 5 & India & 2935.57 & 3.39 & 42.12 & 3.03 \\
\hline 6 & $\begin{array}{l}\text { United } \\
\text { Kingdom }\end{array}$ & 2743.59 & 3.17 & 58.65 & 8.65 \\
\hline 7 & France & 2707.07 & 3.13 & 59.85 & 8.24 \\
\hline 8 & Italy & 1988.64 & 2.30 & 30.9 & 7.04 \\
\hline 9 & Brazil & 1847.02 & 2.13 & 88.32 & 6.12 \\
\hline 10 & Canada & 1730.91 & 2.00 & 45.42 & 7.77 \\
\hline 11 & Russia & 1637.89 & 1.89 & 8.78 & 7.07 \\
\hline 12 & Korea & 1629.53 & 1.88 & 14.48 & 8.85 \\
\hline
\end{tabular}

As of 2019, United States and China would occupy first two places. On nominal basis, US is ahead of China by $\$ 7.3$ trillion in 2019 (table 1) [11]. The U.S. has retained its position of being the world's largest economy since 1871. The size of the U.S. economy was at \$20.58 trillion in 2018 in nominal terms and is expected to reach \$22.32 trillion in 2020.

Over the years, the difference in the size of the Chinese and the U.S. economy has been shrinking rapidly. In 2018, the Chinese GDP in nominal terms stood at \$13.37 trillion, lower than the U.S. by $\$ 7.21$ trillion. In 2020 , the gap is expected to reduce to $\$ 7.05$ trillion, and by 2023 , the difference would be $\$ 5.47$ trillion. In terms of GDP in PPP, China is the largest economy, with a GDP (PPP) of $\$ 25.27$ trillion. By 2023, China's GDP (PPP) would be $\$ 36.99$ trillion.

There are several types of correlation coefficient formulas. One of the most commonly used formulas in stats is Pearson's correlation coefficient formula. 


$$
r=\frac{n\left(\sum x y\right)-\left(\sum x\right)(\Sigma y)}{\sqrt{\left[n \Sigma x^{2}-\left(\sum x\right)^{2} \times n \sum y^{2}-(\Sigma y)^{2}\right]}}
$$

The range of the correlation coefficient is from -1 to 1 .

Correlation coefficient between GDP and Foreign Direct Investment is:

$$
r=\frac{12 \times 9744.8-61.8 \times 941.57}{\sqrt{[(12 \times 740.2-3819.24) \times(12 \times 139832.2-886554)]}}=\frac{58748.6}{63302}=0.92
$$

The result is 0.92 or $92 \%$, which means the variables have a moderate positive correlation.

\section{Cyberspace development}

The effectiveness of management at various levels directly depends on the effectiveness of the functioning of cyberspace.

There is a constant increase in information exchange [22, 23, 24]. Cyberspace is characterized by heterogeneity. The heterogeneity of cyberspace is due to the wide range of services provided by the participants of the information market of services characterized by heterogeneous qualitative and quantitative characteristics [22]. Each fragment of cyberspace is characterized by a certain set of parameters, for example: the number of services offered, range, maximum data transfer speed, operating frequencies, number of access nodes, number of connected terminal devices, number of subscribers, level of solvency of subscribers, etc.

Lets consider the heterogeneity of cyberspace using the applied technologies for developing a communication network as an example. Currently, 2G, 3G and 4G standards are developed and implemented in the world, and the 5G standard is under development.

A fragment of cyberspace highlighting heterogeneities characterized by different levels of technological development is graphically presented in Fig. 2.

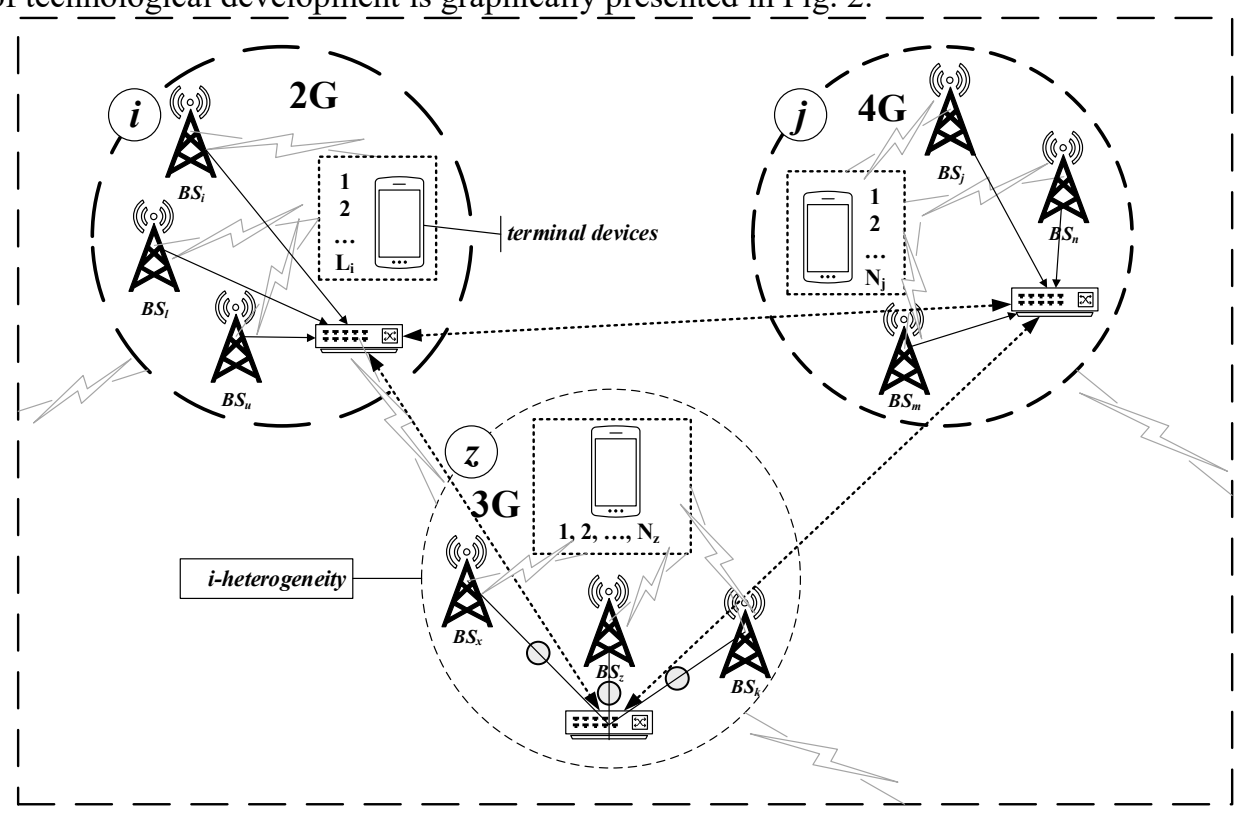

Fig. 2. A fragment of cyberspace highlighting heterogeneities characterized by different levels of technological development. 
The quality of telecommunication services depends on the technical level and development of communication systems, as well as on the terminal equipment of the subscriber. Due to the fact that different communication networks have different technical capabilities and individual quality indicators, the quality of communication will be determined by the worst indicators of fragments of cyberspace used by corresponding subscribers, since the technical level of fragments of cyberspace varies significantly.

The type of communication network is determined by applying the theory of pattern recognition. The recognition task is to assign the considered objects or phenomena according to their characteristic description to one or another reference cluster.

It is logical to assume that by identifying heterogeneities [22] and ranking them according to their characteristics, it is possible to determine the dynamics of changes in the GDP of a country and also to identify the world center of capital accumulation.

The world leader in the development and implementation of fifth-generation $5 \mathrm{G}$ mobile networks is China. In the province of Fujian, the world's first remote medical operation via $5 \mathrm{G}$ networks was performed at the facilities of the Chinese telecommunications giant Huawei.

Fig. 3 shows the fifth generation $5 \mathrm{G}$ mobile communications test sites in the world [21].

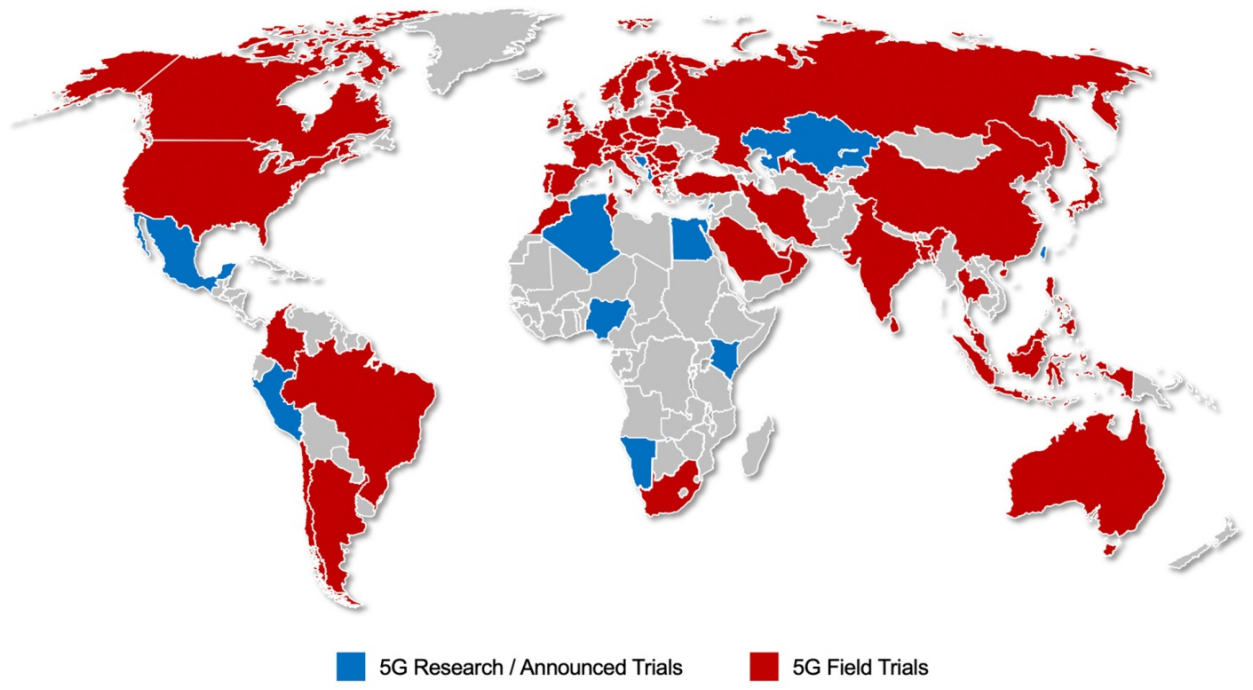

Fig. 3. World map of 5G Field Trials.

Thus, according to Figure 3, now 5G technology is being tested in many countries of the world, but the speed of development and implementation of 5G technology will vary significantly, due to differences in industrial development, allocated funding, and also directly dependent on global manufacturers of $5 \mathrm{G}$ equipment (leaders in currently are USA and China).

So, in some countries, mobile operators are already introducing $5 \mathrm{G}$ networks into commercial operation. For example, in the USA, Qatar and South Korea, where several thousand $5 \mathrm{G}$ base stations operate.

The first 5G networks appeared in the USA in April 2019 - Verizone Communications began providing a new generation of communications in Chicago and Minneapolis. On the same day, South Korea was the first in the world to launch the national $5 \mathrm{G}$ network.

Given that the largest influx of investment falls on industrialized countries that have the most technologically advanced information and telecommunications platform, we can formulate a hypothesis about the formation of a new world center of capital accumulation China. 
The authors developed a technique [22] that allows optimizing the controlled parameters of the innovative development of a specific fragment of cyberspace for the subsequent maximization of profit, the economic essence of which is generally summarized in the implementation of the following steps:

1) the allocation of quasihomogeneous fragments of cyberspace;

2) the identification of the structure of information gravitation of many subscribers identified quasihomogeneous fragments;

3) assessment of the solvency of subscribers on fragments with a lower level of innovation;

4) a comparison of the size of lost profits and the profitability of innovative solutions;

5) assessment of an innovative resource.

Application of the developed methodology will allow obtaining objective quantitative data for each fragment of cyberspace, determining the phase of development of world centers of capital accumulation, and also calculating the amount of investment in a specific world center of capital accumulation.

The indicators identified according to the technique [22] will allow quantifying the rate of change in GDP, since it is the telecommunications sector that ensures the functioning of all sectors of the economy, as well as their effectiveness.

\section{Conclusions}

GDP and Foreign Direct Investment are highly correlated. Correlation coefficient between GDP and Foreign Direct Investment is $92 \%$.

To conclude, the relationship between the dynamics of the development of cyberspace and the dynamics of changes in the volume of GDP is revealed, which allows us to predict changes in the volumes of GDP, as well as the dynamics of changes in world capital, taking into account the various stages of development of national economies.

\section{References}

1. O. Tkacheva, L. Osadchuk, I. Kapustina, I. Kobersy, S. Litvinova, International Journal of Applied Business and Economic Research 15(23), 403-412 (2017).

2. I. Kapustina, T. Kirillova, O. Ilyina, O. Razzhivin, P. Smelov, International Journal of Applied Business and Economic Research 15(11), 1-10 (2017).

3. E. Zolotukhina, V. Bakharev, I. Kapustina, S. Novikov, N. Lygina, International Journal of Applied Business and Economic Research 15(11), 19-27 (2017).

4. A. Bril, O. Kalinina, O. Valebnikova, Lecture Notes in Computer Science (including subseries Lecture Notes in Artificial Intelligence and Lecture Notes in Bioinformatics) 9870 LNCS, 766-775 (2016).

5. M. Davliatova, A. Brechko, N. Lvova, M. Sorokin, IOP Conference Series: Materials Science and Engineering 497, 012131 (2019).

6. E.L. Bogdanova, T.G. Maximova, A.S. Nikolaev, A.A. Antipov, Innovation Management and Education Excellence through Vision 2020 Proceedings of the 31st IBIMA Conference, 6856-6863 (2018).

7. D. Verzilin, T. Maximova, I. Sokolova, Communications in Computer and Information Science 745, 55-69 (2017). DOI: 10.1007/978-3-319-69784-0_5

8. D. Verzilin, T. Maximova, I. Sokolova, S. Skorykh, IFAC-PapersOnLine 52(13), 2261-2266 (2019). 
9. I. Alnafrah, E. Bogdanova, T. Maximova, International Journal of Intellectual Property Management 9(2), 120-135 (2019).

10. D. Verzilin, E. Gorovykh, T. Maximova, I. Sokolova, I. Gokinaeva, Proceedings of the 32nd IBIMA Conference, IBIMA 2018 - Vision 2020: Sustainable Economic Development and Application of Innovation Management from Regional expansion to Global Growth, 5471-5478 (2019).

11. International Monetary Fund World Economic Outlook, (2019) URL: https://www.imf.org/external/pubs/ft/weo/2019/02/weodata/index.aspx

12. S. Krymov, I. Kapustina, M. Kolgan, Proceedings of 2017 IEEE 6th Forum Strategic Partnership of Universities and Enterprises of Hi-Tech Branches (Science. Education. Innovations), SPUE 2017, 122-124 (2018). DOI: 10.1109/IVForum.2017.8246068

13. O. Kalinina, M. Lopatin, Actual Problems of Economics 182(8), 392-405 (2016).

14. O. Kalinina, E. Balchik, S. Barykin, MATEC Web of Conferences 239, 04021 (2018). DOI: $10.1051 /$ matecconf/201823904021.

15. T. Chueva, M. Melnichuk, G. Ruchkina, O. Ilina, S. Litvinova, International Journal of Applied Business and Economic Research 15(23), 245-254 (2017).

16. G. Arrighi, The Long Twentieth Century: Money, Power, and the Origins of Our Times (Verso, London, 1994)

17. N. Kondratieff, The Major Problems of Economic Statics and Dynamics (Nayka, Moscow, 1991) [In Russian]

18. F. Braudel, La dinamica del capitalism (Alianza Editorial, Madrid, 1985)

19. T. Piketty, Capital in the Twenty-First Century (Ad Marginem Press, Moscow, 2015) [in Russian]

20. E. Balatsky, TERRA ECONOMICUS 16(1), 37-55 (2018). DOI: 10.23683/2073-66062018-16-1-37-55

21. World Map of 5G Field Trials (2020) URL: https://5g.security/resources/5g-trialsworld-map/.

22. M. Davliatova, Y. Starodubcev, SPbSPU J. Economics 11(4), 251-262 (2018). DOI: 10.18721/JE. 11420

23. M. Davliatova, Y. Starodubtsev, SPbSPU J. Economics 12(1), 146-158 (2019). DOI: 10.18721/JE.12112.

24. M. Davliatova, Y. Starodubtsev, T. Khnykina, Y. Semenova, IOP Conference Series: Materials Science and Engineering 497, 012116 (2019). 